\title{
Opening the Dissertation: Overcoming Cultural Calcification and Agoraphobia
}

\author{
Denise Troll Covey \\ Carnegie Mellon University, Pittsburgh, PA, troll@andrew.cmu.edu, \\ http://works.bepress.com/denise_troll_covey/
}

\begin{abstract}
This article places the struggle to open access to the dissertation in the context of the crisis in doctoral education and the transition from print to digital literacy. It explores the underlying cultural calcification and agoraphobia that deter engagement with openness. Solving the problems will require overhauling the curriculum and conventions of doctoral education. Opening access to dissertations is an important first step, but insufficient to end the crisis. Only opening other dimensions of the dissertation - the structure, media, notion of authorship, and methods of assessment - can foster the digital literacy needed to save $\mathrm{PhD}$ programs from extinction. If higher education institutions invested heavily in remedying obsolete practices, the remedies would reverberate throughout the academy, accelerate advancement in the disciplines, and revolutionize scholarly publishing. The article ends with a discussion of the significant role librarians could play in facilitating needed changes given appropriate institutional commitment.
\end{abstract}

Keywords: open access, doctoral education, cultural agoraphobia, ETD programs, ProQuest/UMI, literacy, Council of Graduate Schools, Carnegie Initiative on the Doctorate

\section{Introduction}

Throughout history, the capstone projects of doctoral education were to be publicly accessible. Internet technologies enable public access to an extent previously not possible. This article advocates for opening the dissertation, opening not only access, but the choice of structure, media, license for reuse, and notion of authorship to embrace the realities and capabilities of the 21st Century. The primary barriers to opening the dissertation are cultural calcification and agoraphobia. The two are interrelated. Calcified conventions sustain the linear structure of print and the Romantic notion of the solitary author and drive fears of openness. Entrenched cultural conventions and old-school mentors hold doctoral students hostage to their practices and perceptions. Forward thinkers are challenging these conventions and fears, including the continued practice of enabling ProQuest/UMI to profit from disseminating dissertations.

This article places the struggle to open the dissertation in the context of the crisis in doctoral education and the transition from print to digital literacy. It examines what the dissertation was in the medieval, print and microform eras, what it is now in the troubling period of transition to deeply interiorized digital literacy, and what it could be if liberated from 19th Century print literate habits. The article explores the underlying cultural calcification and agoraphobia that deter engagement with openness, preventing students from realizing their full potential and PhD programs from graduating stewards of their discipline. Solving the problems will require overhauling the curriculum and implementing interventions that affect students, faculty and staff across the academy. Opening access to dissertations is an important first step, but insufficient to end the crisis. Only opening other dimensions of the dissertation - the structure, media, notion of authorship, and methods of assessment - can foster the digital literacy needed to save $\mathrm{PhD}$ programs from extinction. If higher education institutions acknowledged and invested heavily in remedying obsolete practices in doctoral education, the remedies would reverberate throughout the academy, accelerate advancement in the disciplines, and revolutionize scholarly publishing. The article ends with a discussion of the 
significant role librarians could play in facilitating needed changes given appropriate institutional commitment.

\section{Crisis in Doctoral Education}

PhD programs are in crisis. Research conducted by the Council of Graduate Schools (CGS) revealed that 40-50 per cent of those who enrol in a PhD program in the United States and Canada fail to earn a PhD (Sowell 2008). Yet there is a glut of PhD graduates. Many of those who earn the degree cannot find jobs in their field. Among those who do find jobs in their field, many are stigmatized by the academy for failing to find a tenure-track position. ${ }^{1}$ Many PhDs working in their field work in government or industry or eke out a meagre existence as part-time adjunct faculty, ${ }^{2}$ without benefits, job security, collegiality from full-time faculty, or an income sufficient to live comfortably and pay off their education loans. The number of people with $\mathrm{PhDs}$ receiving some kind of public assistance more than tripled from 2007 to 2010 (Patton 2012).

Like a horse wearing blinders to avoid distraction or panic, the CGS proposed extracurricular interventions to increase $\mathrm{PhD}$ completion rates. It proposed workshops to improve faculty advising during the dissertation stage, ${ }^{3}$ and providing writing assistance and support retreats to meet student needs at the dissertation stage. It also recommended professional development seminars to improve the quality of student teaching and (finally) to prepare students for careers outside the academy (CGS 2010). These interventions are woefully inadequate to address the overarching problem identified by the Carnegie Initiative on the Doctorate (CID).

According to the CID, "doctoral education may have lost sight of its central purpose" (Golde 2006, p. 4). Academic traditions have not kept pace with the developmental needs of students. Many PhD graduates working in their field are not well prepared to function effectively in the academy, government or industry. Times and conditions have changed, but the academy continues obsolete practices. The curriculum and conventions must be overhauled to bring them into the $21^{\text {st }}$ Century.

The purpose of doctoral education is to prepare stewards of the disciplines. The CID defines stewardship as both a set of roles and skills that ensures competence and a set of principles that provides a moral compass. PhD recipients should be highly accomplished at generating new knowledge and critiquing knowledge claims, conserving the legacy of their discipline, and transforming knowledge through creative application and effective communication to different audiences and in different media. The notion of stewardship brings the crisis in doctoral education to the heart of the debate about open access: "Perhaps most important, a steward considers how to prepare and initiate the next generations of stewards. By invoking the term steward, we intend to convey the sense of purpose that guides action. Selfidentifying as a steward implies adopting a sense of purpose that is larger than oneself. One is a steward of the discipline, not simply the manager of one's own career" (Gold 2006, p. 13).

As we will see later in this article, when asked to choose between open or restricted access to their dissertation, many doctoral students focus on managing their own careers. They restrict access or delay open access to their work, sacrificing stewardship of their discipline to their fear of openness. What is at play here is a profound cultural and cognitive tension between the safe and familiar closure of print literacy and the wild and unknown openness of

\footnotetext{
${ }^{1}$ Universities and scholarly societies only recently began to prepare doctoral students for "alternative" jobs outside of the academy for those who cannot - or choose not to - find a tenure-track position in a university (Ellis 2013).

2 The academy has become increasingly reliant on adjunct faculty, despite the deleterious effects on student graduation rates and the quality of life of the adjuncts themselves. In 2009 , over 50 percent of higher-education faculty were part-time adjuncts (Sabga 2013).

${ }^{3}$ Advising is the second most significant factor determining whether a student earns a PhD, trumped only by financial support (CGS 2009). Students rate the availability of their advisors to meet with them about their dissertation far behind their availability to meet with them about coursework, qualifying exams, or preliminary exams (Jaschik 2009).
} 
digital literacy. Understanding the relationship between technology and literacy and the historical trajectory of the doctoral dissertation will clarify the current predicament and the urgency of heeding the CID's call to update the curriculum and conventions of doctoral education for the $21^{\text {st }}$ Century.

\section{Technology and Literacy}

The Oxford English Dictionary defines literacy as "the quality, condition, or state of being literate; the ability to read and write" ("Literacy" Def. 1). The definition is rooted in manuscript and print culture. Over time, the term was modified and defined as "the ability to 'read' a specified subject or medium" ("Literacy" Def. 2). The Joint Information Systems Committee (JISC) defines digital literacy as "those capabilities which fit an individual for living, learning and working in a digital society." Digital literacy is the integration of computer literacy, information literacy, media literacy, the ability to communicate and collaborate using digital networks, to participate in research and scholarship dependent on digital systems, to study and learn using technology, and to use digital tools and media to make informed decisions and achieve goals (JISC 2011, p. 2).

According to Walter J. Ong, technologies of the word - from manuscript to print to computers - reorganize the perceptual and cognitive styles of the people who use them (1982). New technologies initially depend on and reinforce the former technology, but over time, with generations of use, they transform the former as the possibilities inherent in the new technology are realized. The printing press initially mass-produced the manuscript codices copied by medieval scribes. Generations later, new genres such as the novel appeared.

The progression is inevitable. With repeated and widespread use, human beings interiorize the capabilities of a new technology. The constraints on perception and thought imposed by the former technology slowly drop away. Eventually the new capabilities fuse with human consciousness, conferring freedoms that only the new technology can provide. James J. O'Donnell describes these freedoms as "new range and power and intimacy" (1998, p. 157).

The capabilities of digital technologies are rapidly being interiorized, changing how we think and how we see ourselves and the world around us. We are in different stages of this process, on our way to deeply interiorized digital literacy. Lorcan Dempsey places Internet users on a continuum of engagement with the web, from visitor to resident (2012). Visitors see the web as a collection of tools for building skills. Residents see the web as a series of co-present spaces for interacting with others and creating an online presence. The disparity in where we are on this continuum creates a cultural and psychological chasm, for example, between aging professors with entrenched print literate habits and so-called digital natives who never knew the world without the web.

To meet the needs and expectations of students and employers in the digital era, the curriculum and culture of doctoral education must be liberated from the constraints of print and embrace the freedoms that only digital technologies can provide. The liberation will be a painful struggle between those responding to the call to openness coming from digital technologies and those clinging to the retrograde closure of print. ${ }^{4}$ Openness will inevitably win, with the support of the academy or its competitors. ${ }^{5}$ To trounce the competition, the academy must be proactive. Understanding how the capstone project in doctoral education evolved or devolved to the point that it fails to demonstrate the competencies and principles of stewardship needed in the digital era will help us see what we must do to recover.

\footnotetext{
${ }^{4}$ According to Walter J. Ong, writing is a closed system compared to speech. Writing exists on its own, independent of the author and reader. Print technology is more closed than manuscript technology, though it is also open and liberating, providing access to information otherwise inaccessible and enabling new thought processes. Today we live in a culture drawn to an openness connected to electronic and digital technologies (Ong 1977).

${ }^{5}$ See, for example, the American Council of Trustees and Alumni (ACTA) article Much Needed Competition Coming to Higher-Ed, June 28, 2013. Accessed November 15, 2013.

http://www.goacta.org/the_forum/much_needed_competition_coming_to_higher_ed
}

CC: Creative Commons License, 2013. 


\section{Evolution of the Doctoral Dissertation}

The doctoral dissertation is a microcosm for examining the crisis in doctoral education. It illustrates the slow transition from manuscript literacy to print literacy to digital literacy. We need to understand how the dissertation came to be what it is and speculate about what it could be if liberated from current constraints. We need to appreciate what is at stake.

\subsection{The Middle Ages}

The medieval disputatio was the public performance of a debate designed to test the competence of the student and to add to the scholarly record. Disputation was the doctoral student's final exam, but it was also the primary learning and research method in the medieval university. Colluccio Salutati (1330-1406) chastised students for neglecting the practice, arguing that nothing was more useful to learning, to refreshing and restoring the mind and sharpening ingenuity than discussing subtle matters from different perspectives with others. For Salutati, it was "absurd to talk with oneself between walls and in solitude" when disputation offered so many advantages (Salutati on Disputations, p. 267).

The doctoral disputatio demonstrated the student's ability to generate insights and critique claims, to understand and preserve prior work through use, to creatively apply new insights that added value to this legacy, and to effectively communicate to a public assembly. The student who argued competently proved he was a steward of the discipline. He received the doctorate degree and "the power of occupying a chair, of lecturing in universities, disputing publicly, interpreting, glossing, and the like" (Getting a Degree). Disputations were open to public participation within specified constraints: "And if outsiders chance to attend these disputations, if they are persons of good repute, which should be left to the judgment of the master of students, and are not so numerous as to impede the fellows of the house from their own exercise, if they wish to argue, they shall be allowed to do so according to their degrees; or, if anyone has no degree, provided he is a noble or cleric or enjoys other prerogative, the master of students shall place him in the arguing as it seems fit to him" (Disputations in the Collège de Sorbonne, pp. 199-200).

\subsection{The $19^{\text {th }}$ and $20^{\text {th }}$ Centuries}

In the $19^{\text {th }}$ Century, German universities made a written dissertation a requirement for receiving a doctoral degree. The requirement was swiftly adopted in the United States. The dissertation exercise, inseparable from the $19^{\text {th }}$ Century notion of the author as someone who labours alone to advance knowledge, focused on applying the principles of responsible conduct in the discipline to the generation of new knowledge communicated in writing. The solitary work of the author was to demonstrate to others in the discipline that the student had sufficient expertise, self-discipline, and originality to advance the discipline. Centuries earlier, Salutati decried this approach as absurd.

The oral dissertation defense, reminiscent of the medieval disputatio, invited public participation, but the written work was paramount. The pages were bound and placed on a library shelf. There they met the requirement of public accessibility, but gathered dust rather than readers or interlocutors. Print technology made dissertations difficult to discover and expensive to reproduce and distribute. Copyright law, developed in the $18^{\text {th }}$ Century, further complicated reproduction and dissemination.

In the early $20^{\text {th }}$ Century, the situation improved slightly with the founding of University Microfilms Inc. (UMI) in 1938. UMI improved discovery and access by compiling and selling a bibliographic index and microfilm copies of American dissertations. ${ }^{6}$ In 1951, the Association of Research Libraries (ARL) recognized UMI as the publisher of record for all U.S. dissertations. In 1987, UMI began selling abstracts and an index of dissertations on CD ROM. A

\footnotetext{
${ }^{6}$ For decades UMI retained the exclusive right to publish the dissertations. This limited access to those who could afford to pay and limited collection development by prohibiting U.S. libraries from exchanging copies of American dissertations for dissertations produced abroad (Ash 1969). Copying for personal or educational use was prohibited in the United States until the Copyright Act of 1976.
} 
decade later, it was selling access to and copies of the full text of digital dissertations (ProQuest). By the end of the $20^{\text {th }}$ Century, UMI had created a profitable monopoly in the dissertation trade with the full support of research libraries and universities, many of which required and continue to require the deposit of completed dissertations in the ProQuest/UMI ${ }^{7}$ digital dissertations database

\subsection{What the Dissertation is Now}

Dissertations today are $21^{\text {st }}$ Century replicas of $19^{\text {th }}$ Century linear narratives. The notion of the solitary author creating original work remains intact, understandable in a balkanized academy where some champion but most deny the social construction of knowledge (Woodmansee and Jaszi 1995). Reviewers in the field ensure that dissertations reflect two of the three accomplishments that constitute stewardship of the discipline according to the CID. Dissertations must (1) generate new knowledge and (2) include a literature review acknowledging prior work. They need not (3) transform knowledge through creative application and effective communication to different audiences and in different media. Turning a dissertation into a monograph that appeals to a broader audience occurs, if at all, after graduation and after substantial revision.

Though digital technologies have liberated us from the constraints of print, most dissertations are PDF files designed to resemble and enable print and to prohibit full text searching and easy manipulation. Though digital dissertations are increasingly available online, few exploit the opportunities afforded by digital technologies. The number of multimedia dissertations is miniscule compared to the total number of dissertations produced (Swain 2010, Salmi 2008, Brown 2010, Fyffe and Welburn 2008, Fineman 2003). Depending on the authors' choices regarding online dissemination and copyright management, digital dissertations might not be more easily discovered or used than their print counterparts.

Some institutions continue the oral dissertation defense, but in the United States the defense is often merely a formality, an ornamental rite of passage attended by faculty on the dissertation committee, family members, and a few interested colleagues. The defense is not an examination because the work has been accepted prior to the event. Disputes (disputatio) are seldom public affairs unless faculty members in the audience squabble with one another to the chagrin of the stranded student (Cassuto 2012). Recent innovations that engage the public and transform knowledge through creative application and effective communication to different audiences and in different media, such as the Three Minute Thesis (3MT TM $)^{8}$ competition and the Dance Your PhD contest, ${ }^{9}$ exist outside formal assessments for awarding the $\mathrm{PhD}$.

Until recently, the academy that nurtured the production of dissertations seemed to lose interest in them before the ink on the authorizing signatures was dry, abandoning them as gray literature unworthy of the limelight. Required or optional deposit in the library or the ProQuest/UMI digital dissertations database was a final formality guided by a checklist of steps endured or ignored by harried students. As a result, the authors' hard work languished in obscurity on a bookshelf or behind a paywall upon graduation. Graduate programs tallied annual statistics on the number of $\mathrm{PhD}$ recipients, perhaps tracked their starting salaries as a future recruitment strategy, and no doubt started treating them as potential donors to the school. How dissertations in this environment really served the discipline or the author is unclear.

Dissertation dissemination practices are changing. Universities are increasingly adopting electronic theses and dissertation (ETD) programs, requiring or encouraging deposit in the institution's open access repository. The programs allow exceptions and embargoes on open access to address author concerns. The push has been for gratis open access, meaning free public access to the full text of the work. Preferable to gratis open access is libre open access, which grants free public access to the work and designated re-use rights under an

\footnotetext{
${ }^{7}$ UMI was rebranded ProQuest in 2001.

${ }^{8}$ See http://threeminutethesis.org/.

${ }^{9}$ See http://gonzolabs.org/dance/.
} 
open license. The uptake of open access and open licensing has been slow. ETD programs suffer from a low rate of participation (Salmi 2008). Authors who do participate often choose to restrict or embargo access to their work. ${ }^{10}$ Perhaps wary of the competition presented by ETD programs, in 2007 ProQuest/UMI began offering a gratis open access option for dissertations - for a fee substantially higher than their fee for traditional (restricted access) publishing.

Graduate students and research institutions are becoming increasingly disenchanted with UMI's monopoly on dissertations, now that institutional repositories offer a viable alternative. Graduate students are objecting to UMI fees, paywalls, and delays (FUSE 2012-2013). ${ }^{11}$ Research institutions with ETD programs are realizing they can create a more comprehensive collection of their dissertations than UMI can, and that their fears of losing prominence if their dissertations are not included in the ProQuest/UMI database are unfounded. Some institutions stopped requiring deposit in the UMI database years ago. ${ }^{12}$ ProQuest/UMI saw a precipitous drop in submissions from these institutions (FUSE 2013a). ${ }^{13}$

Gail Clement and Fred Rascoe recently compared ETD publishing in an institutional repository with publishing in the ProQuest/UMI database (2013). They identify implications for practice that bring the current state of disseminating dissertations into sharp focus:

- Stakeholders in scholarly publishing need to re-examine assumptions about dissertation management and dissemination developed in the print and microfilm eras.

- Decisions based on operational convenience or hoped-for royalties may be at odds with $21^{\text {st }}$ Century graduate education, digital scholarship, and scholarly publishing.

- Student attitudes and expectations may conflict with the status quo practice of ETD submission to ProQuest/UMI.

- Research institutions that have dropped required deposit in ProQuest/UMI provide a successful model for other institutions.

\subsection{What the Dissertation Could Be}

Imagine a dissertation that leverages the full potential of graduate students and digital technologies. It is freely available online. It contains multimedia digital objects, e.g., colour graphics, animations, simulations, visualizations, video and audio. Using hypertext links readers can access the underlying data and navigate to the prior work built upon, both primary and secondary sources. Different paths are provided through the work, enabling readers to interact with it and traverse it from multiple perspectives, the author having become decentred and empowered to orchestrate many voices reminiscent of the medieval disputatio. Imagine this dissertation serving as the hub of an ongoing conversation. Readers can annotate or comment on it and share their remarks with other designated readers or with the entire world, adding their voices to the scholarly record.

Imagine this dissertation with few if any restrictions on use, the author committed to sharing her work and effectively managing her copyrights. Readers can re-use the author's text, multimedia objects, and underlying data without asking permission. They can copy the work and carve a new path through it or change a path already carved. They can add another

\footnotetext{
${ }^{10}$ For example, statistics on ETDs at Virginia Polytechnic Institute, the home of the first ETD program, show that access to $45 \%$ of the dissertations is restricted. Digital Library and Archives etds@vt. Accessed October 6, 2013. http://scholar.lib.vt.edu/theses/browse/by_author/

${ }^{11}$ In 2011, a graduate student wrote a manifesto requesting a waiver from Texas A\&M's requirement of deposit with UMI, stating "Neither A\&M, nor its students have any obligation to enrich ProQuest's database, thereby enabling it to have a stranglehold on the ETD and academic publication market." The request was granted. Accessed November 3, 2013. http://sites.tdl.org/fuse/?p=31

${ }_{12}$ Doctorate-granting institutions that have made deposit in the ProQuest/UMI digital dissertations database optional include Georgia Institute of Technology, Louisiana State University, Stanford University, University of Central Florida, University of Michigan, University of Tennessee-Knoxville, and University of Texas-Austin.

${ }^{13}$ In response, ProQuest/UMI raised the cost of abstract-only submissions to $\$ 65$, eliminated the $\$ 65$ fee for fulltext submissions made using its proprietary submission system, and reduced the fee to $\$ 25$ for FTP or CD/DVD submissions (FUSE 2013b, Hadro 2010).
} 
voice or change the arrangement of voices. They can mine the work as part of a larger corpus of works or use it in ways and for purposes we cannot even imagine.

Now imagine dispensing with the $19^{\text {th }}$ Century notion of the author working in solitude. Imagine embracing the notion that knowledge is socially constructed, embracing how the real world works, in teams and interdisciplinary collaborations. Imagine the capstone project in doctoral education as an exercise designed to prepare students to work in this world. Imagine what the dissertation could be as a collaborative effort of graduate students gifted in different ways, some verbal, some quantitative, and some technological. Imagine collaborative dissertations and review committees capable of assessing such works, of recognizing that all author roles are not equal and all contributors are not authors (Hames 2012). Graduate students permitted and empowered to orchestrate such a dissertation would truly be stewards of the discipline. And scholarly publishing as we know it now would end.

\section{Opening the Dissertation}

If the doctoral dissertation is to demonstrate the competencies and principles of stewardship in the $21^{\text {st }}$ Century, it must be open. Opening access is a critical first step, but open access alone cannot solve the crisis in doctoral education. Subsequent steps must dispense with the $19^{\text {th }}$ Century model of scholarly work and open the structure and media of dissertations, the notion of authorship, and the criteria for assessment. Given current calcified conventions and fears, higher education institutions will need to pry the dissertation open with a crowbar.

\subsection{Open Access}

The many benefits of opening access to dissertations are well documented. Authors benefit from easy discovery and access to their work (Swain 2010), improved speed and breadth of dissemination (Brown 2010), and increased visibility, use, and impact, which can help them embark on their careers (Salmi 2008, Copeland 2008, Herther 2010). Institutions also benefit from the increased visibility, which advertises the quality of work produced at the institution and can help recruit faculty and students (Yiotis 2008, Salmi 2008, Fyffe and Welburn 2008, Herther 2010, Swain 2010). Disciplines benefit because the work is readily available to build upon and can reduce redundant research (Swain 2010, Brown 2010). Users benefit from easy access to important work. Most importantly, opening access to the dissertation brings the author's identity and contribution out of obscurity and into the arena of respected, marketed, and branded scholarship. The respect and attention have and will continue to improve the quality of the work produced by doctoral students (Suber 2006, Bishop et al 2007, McColl in Swain 2010).

Despite the many benefits of opening access to dissertations, intractable barriers remain, entrenched in a print literate culture that fears the openness inevitably coming with digital literacy. The primary reasons given for not opening access to the dissertation are fear of not publishing future work based on the dissertation, fear of copyright infringement, and fear of plagiarism and idea theft (Edminster and Moxley 2002, Copeland 2008, Yiotis 2008, Salmi 2008, Brown 2010, McCutcheon 2010, Tarrant 2012b). Note that none of these fears attached to the medieval disputatio. They surfaced with copyright laws and intellectual property rights. They existed with print dissertations, but the inaccessibility of printed copies lessened them. Online access exacerbates them. Open access can exacerbate them even more. Note too that these fears run counter to the CID's notion of stewardship. The fearful are focused on managing their own careers in a print literate world, not managing their careers or advancing their disciplines in a digital world. They are visitors, not residents on the web. If motivated by fear, those who choose not to open access to their dissertation and those who advise them to make this choice are not good stewards.

Many open access advocates characterize these fears as unwarranted or manageable with accurate information and effective ETD program options. For example, 
- Students can investigate whether the primary publishers in their discipline consider open access dissertations to be prior publications. ${ }^{14}$ If they do, open access can be delayed or the student can change her initial distribution option (McCutcheon 2010).

- Plagiarism is easier to do online than in print, but it is also more easily detected online than in print (Yiotis 2008). ${ }^{15}$ Students should weigh the tradeoffs - the risk of obscurity versus the risk of plagiarism - and if necessary delay open access. Ideas are not copyright protected, but they can be protected by delaying open access.

Some who believe these fears are manageable push for a final teachable moment between completion and submission of the dissertation, when appropriate intervention can garner the author's permission to provide open access to her work (Carlson 2013, Reich and Tenen 2012). I contend that the final teachable moment is a myth because it occurs, if at all, too late in the process and because it ignores the more general, pervasive, pernicious fear arising from the cultural calcification of print literate habits. In this painful period of transition from print to digital literacy, many people suffer from what James Boyle calls cultural agoraphobia, a cognitive bias that leads us to underestimate the potential of openness (2009). People fear being helpless in wide open or crowded public spaces where they have no control. Virtual public space, wide open and crowded, can heighten the anxiety.

Students preparing to submit the final version of their dissertation are in the last stage of their epic journey from apprentice to scholar. Most are probably thinking of a celebratory beer rather than carefully studying the policies, procedures, dissemination options, and legal agreements that control the future of their dissertation. Who at that point would contact publishers to discover their position on open access dissertations or begin seeking copyright permissions ? $^{16}$ Expecting exhausted students to perceive as a final teachable moment what those around them treat as a final bureaucratic step reduced to a checklist is wishful thinking. If we want students to make their dissertations available open access under an open license, they need to know ahead of time which options to choose and why when the time comes. They need to understand the issues early, know what is at stake, and make informed decisions based on facts, not fear. But those who influence their choices - their advisor, scholarly society, perhaps even the department secretary - likely do not know the facts, probably suffer from cultural agoraphobia, and are accountable to no one when they spread their fears and misconceptions. ${ }^{17}$

Institutional commitment is essential to the success of an ETD program and to opening access to the dissertation. Many studies show that institutional commitment is lacking one way or another. Inappropriate policies and procedures, inadequate program promotion,

\footnotetext{
${ }^{14}$ Concerns about prior publication are overblown. Most publishers view dissertations as gray literature or preprints, not prior publications; they require substantial revisions to turn a dissertation into a book marketable to a broader audience (Fyffe and Welburn 2008, McMillan et al 2011, Edminster and Moxley 2002, Yiotis 2008, Seamans 2003, Bishop et al 2007). Some publishers find dissertation-based work more appealing if the original work attracted an audience online (Tarrant 2012a). A survey of Virginia Tech graduates revealed that those who published work based on their open-access ETD within two years of graduation encountered no resistance from publishers (McMillan 2005).

15 The blog Retraction Watch frequently reports retractions because of plagiarism. See http://retractionwatch.wordpress.com/.

${ }^{16}$ Students should understand and manage copyright effectively before they submit their dissertation because their prior choices can constrain their dissemination options. Authors need to understand their copyrights and steward them wisely. They also need to respect other people's copyrights. Requiring this of doctoral students would teach them the importance of copyright management and open licenses. Moreover it would teach them how the real world they are about to enter works.

${ }^{17}$ Whether faculty are increasingly advising students to restrict access or to provide open access to their dissertations appears to vary across institutions, disciplines, perhaps even nations (McMillan 2005, Salmi 2008, Brown 2010). Students with advisors who support open access are the most enthusiastic about opening access to their dissertation (Brown 2010), but often advisors do not know the dissertation dissemination options available to students (Myers and Galarza 2011). Advisors can spread their unwarranted fears and misconceptions about open access, copyright, and publisher positions on ETDs (McMillan 2005, JISC and the British Library 2012). Their fears inform statements issued by scholarly associations warning against opening access to dissertations, a position increasingly out of step with graduate students in the discipline (Galarza 2011). Students who want open access should not be dissuaded by others resistant to change (Copeland 2008).
} 
vaguely assigned responsibilities, and insufficient resources allocated for infrastructure, staffing, or training of students and their advisors discourage participation in an ETD program (Yiotis 2008, Salmi 2008, Copeland 2008). Concerns about ETDs requiring additional work or skill and concerns about software or format obsolescence and long-term preservation of ETDs can likewise deter participation or even the development of an ETD program (Edminster and Moxley 2002, Copeland 2008, Yiotis 2008, Salmi 2008, Fyffe and Welburn 2008, Brown 2010). These concerns are not insignificant, but they can be addressed with careful planning, advocacy, and institutional commitment to change.

For the short term, perhaps the best we can do is to require students to deposit their dissertations in the institutional repository and allow the wary to restrict or delay open access to their work. There are compelling reasons not to provide immediate open access to a dissertation, but we need to investigate what motivates this choice. If the motivation is fear, it should be addressed with institutional force. Those who limit access to their dissertation out of fear are not good stewards of their discipline. They are hoarders ${ }^{18}$ and censors who undermine the values and mission of the university, upset the balance between private interest and public good that copyright was designed to achieve, and impair the online identity critical to their future employment (Edminster and Moxley 2002, Tarrant 2012a).

If institutions are committed to graduating stewards of the discipline unafraid of openness and willing to share their work, they need to start by educating the faculty about open access. Dissertation advisors in particular need to know what is expected of them in this regard. We have the infrastructure to support open access, we know the benefits of it, and it is the only dimension of openness complacent about print literate conventions. However, solving the crisis in doctoral education will require far more than open access.

\subsection{Other Dimensions of Openness}

The benefits of opening other dimensions of the dissertation - the structure, media, notion of authorship, and criteria for assessment - are not well documented, but the crisis in doctoral education indicates the urgency of dispensing with calcified print literate conventions. Requiring $\mathrm{PhD}$ students to engage with openness, giving them the know-how and wherewithal to leverage the possibilities inherent in new technologies will help meet their developmental need for digital literacy. Allowing and empowering students to create digital dissertations liberated from $19^{\text {th }}$ Century constraints will enhance doctoral education and improve the quality of dissertations and graduates (Yiotis 2008, Edminster and Moxley 2002). Digital dissertations could be collaborative public performances, liquid, living works in which many voices interact with one another and with primary and secondary sources. They could transform knowledge through creative application and effective communication to different audiences and in different media - the CID's third competency requirement for earning a PhD. Furthermore, dissertations that demonstrate the new range and power and intimacy afforded by digital technologies will accelerate advancements in the disciplines and change scholarly publishing forever. According to O'Donnell, "The struggle for us today ... is to balance old models with new modes of behavior that exploit the possibilities of the new environment effectively without disorienting us so completely that we forget who we are" (1998, p. 13).

The barriers to opening more than access to the dissertation are deeply entrenched. Findings from a study of the research behavior of Generation $Y$ doctoral students (born 19821994) shed light on our current predicament and suggest what must change to enable other forms of openness (JISC and the British Library 2012):

- Dissertation advisors have a decisive role and influence on graduate student research behaviour. Many are admitted technophobes. Doctoral students mimic their traditional and conservative work practices and turn to them for advice about what resources to use.

\footnotetext{
${ }^{18}$ The CID builds on the notion of stewardship in the biblical Parable of the Talents. A man entrusts three servants with some of his coins. He rewards the two who took risks and doubled their holdings, and punished the one who hoarded and saved the money.
} 
- Doctoral students and their advisors do not understand open access, copyright, or the networked scholarly communications environment in which they work.

- Institutions are not engaged with new technologies. The lack of engagement undermines the credibility and legitimacy of these technologies.

- Citation-based assessment programs grant authority and legitimacy to peer-reviewed secondary sources. They undermine the use of unpublished and original material, which is changing the nature of scholarship.

In short, opening the dissertation is constrained by the conservatism of dissertation advisors, the curriculum of doctoral education, institutional indifference to digital technologies, and calcified conventions of assessment of what constitutes legitimacy and credibility. Many doctoral students suffer from a kind of academic Stockholm syndrome, mistaking their advisors' uninformed advice for kindness rather than ignorance and intimidation. The academy refuses to admit that the solitary author is an endangered species; that authoritative discourse does not come from a single voice, but from a dialogue of voices, a disputatio. We refuse to see that discourse need not be fixed to be valid; fixity ensures obsolescence. By clinging to obsolete practices, we unnecessarily constrain student work and cripple their education and employment prospects. The only way out of this mess is to admit that the current techniques of research and scholarship are nothing more than "the pedantic tools of comfortable bourgeois professors seeking to preserve a social and cultural order" (O'Donnell 1998, p. 145). PhD recipients are not well served by requirements that confer status without helping them acquire the capabilities needed for future work in the knowledge economy (Fineman 2003, Copeland 2008).

The CID recommends an overhaul of the curriculum and conventions of doctoral education to realign them with the developmental needs of students in the $21^{\text {st }}$ Century. I contend that this realignment must include opening the dissertation in all its dimensions so that PhD students can demonstrate that they have acquired the requisite competencies and moral compass to live comfortably and work responsibly in an open, networked environment, i.e., that they have acquired the capabilities that constitute digital literacy in their discipline. Transforming knowledge through creative application and effective communication to different audiences and in different media is not possible if the author and her dissertation remain mired in the $19^{\text {th }}$ Century.

If we do not renovate the curriculum and conventions driving doctoral education, it is doomed. Human consciousness will deeply interiorize the capabilities of digital technologies, within or without the academy. The conventions of print will slowly but inexorably give way. Scholarly publishing will one day be transformed along every dimension of openness because these freedoms are inherent in digital technologies. We can resist or facilitate this transformation, but it will not be stopped. According to JISC, "[...] the widespread use of web 2.0 technologies and accompanying social practices have shifted the focus away from a consume-create, or a research-publish model, and towards a model of knowledge in constant circulation (produce-circulate-enrich-reproduce). This means that any definition of digital literacy needs to include participation in social networks as a central element of knowledge production and reproduction, and of being critical in the digital age" $(2011$, p. 3).

Sean Michael Morris puts it more poetically and forebodingly in his Sermon for the Digital Human: "The opportunity for a new digital scholarship has emerged, but it requires a determination and risk that writing has not demanded of us since the dawn of the university. Now to write as academics are accustomed is to copy by hand in the age of the printing press. Speed, movement, alteration, collaboration (in the moment, sirs, not in offices and coffee shops, but in the digital), these have killed the academic genre. The digital is personable, unique and individual. The cloning done in the labs of the academy fails to embrace the thriving, thrashing, teeming world of digital language, symbol, and sign. The lobotomized salmon does not spawn. Not in these waters" (Morris, 2013). 


\section{Ending the Crisis in Doctoral Education}

Overhauling the curriculum and conventions of doctoral education to realign them with the developmental needs of students in the $21^{\text {st }}$ Century will require a significant institutional investment in rethinking current academic practice in its entirety in light of technological developments and the future employability of PhD recipients (JISC 2011). The new curriculum must be designed to develop digital capabilities among graduate students, their advisors, teachers, librarians, and staff with whom they interact. The task is monumental. Participation must be required and stakeholders much be held accountable.

The capabilities that constitute digital literacy vary across the disciplines, though there are some commonalities. The discipline-specific components of the new curriculum are far beyond the scope of this article. Each discipline must carefully select the content, activities, and tools to be embedded in its curriculum. However, the common elements that each discipline should address are in scope. Lessons on the following are needed across the curriculum, all of them engaged with the openness of digital technology:

- Copyright - What it is, how to manage it effectively, the ethical limits of authorship rights, and the dangers of privileging author rights over public rights (Edminster and Moxley 2002, Fineman 2003, Copeland 2008, Torres 2012, Smith July 2012). ${ }^{19}$

- Publishing - The practices and economics of scholarly publishing and the benefits of open access and open licenses (Fineman 2003, Copeland 2008, JISC and the British Library 2012).

- Digital environment - The networked environment in which students and researchers work, the role social media play in scholarly communications, how to use web authoring and other digital literacy tools to explore new ways to make meaning, ${ }^{20}$ why and how to create and manage an online academic presence, what it means to be a digital professional, and how public engagement facilitates the generation, conservation, and transformation of knowledge (Swain 2010, JISC and the British Library 2012, Minocha and Petre 2012).

- Metrics - What they are, and how they should and should not be used to assess the breadth and speed of scholarly impact across the social web (Priem et al 2011).

Those who receive a PhD, regardless of discipline, should be digital residents with the competencies and moral compass to steward their discipline responsibly in the digital environment.

Digital dissertations are an unprecedented opportunity for faculty and students to embrace openness, develop digital literacy, learn what it means to steward their discipline in the digital era, and drive needed changes in scholarly publishing. Free of coercion to transfer copyright, free of the print literate constraints of a publisher's submission guidelines, the dissertation is the ideal venue for experimentation. Students who have produced the new breed of dissertation, who have experienced and exercised the new range and power and intimacy of digital technologies, will be comfortable with openness. And they will not tolerate the current confines and commercialization of scholarly publishing. There will be no going back.

\section{Leveraging Librarians}

Libraries have always contributed to stewarding the disciplines by preserving and providing access to information resources that facilitate the generation and transformation of knowledge. Technological developments have enabled them to improve resource discovery and access and to participate in transforming research and scholarship. Libraries are key players in, if not instigators, of institutional repositories and ETD programs.

\footnotetext{
${ }^{19}$ Privileging author rights over public rights makes scholarly work more difficult and expensive to do (Edminster and Moxley 2002).

${ }^{20}$ Reading and composing a multimedia work or hypertext requires different skills from reading and composing a linear narrative containing a few tables and graphs.
} 
The library appears in the dissertation submission process quite late in the game, usually after departmental administrative staff has worked through a dissertation checklist with the student to ensure that the work complies with program requirements. Library websites typically provide a checklist for submission of dissertations, advice about copyright as it pertains to dissertations, the ProQuest/UMI agreement, and an agreement for submission to the institutional repository. We have much more to offer and to offer earlier in the timeline.

Librarians can contribute to the curricular needs of $\mathrm{PhD}$ students and their advisors. We can teach them about the networked scholarly communications environment in their discipline, including publishing practices and economics and the benefits of open access. We can teach them about copyright and how to manage it effectively for their own and the public good, about the importance of creating an online presence and how to manage it to advance their career, and about traditional metrics and alternative metrics for measuring scholarly impact. We can dispel unwarranted fears of openness and work with students and their advisors to address legitimate concerns about opening access to the dissertation. We can explain the ProQuest/UMI agreement and fees to students and why free deposit in the institutional repository is preferable for the long-term health of their discipline. We can explain the steps we are taking to safeguard the integrity of work deposited in the repository and to ensure its long-term access and preservation.

Engaging the faculty is key to leveraging what the library has to offer. Faculty tend to undervalue the services offered by the library, despite the fact that they and their students have needs that are not being met (MacColl and Jubb 2011). Librarians and senior administrators must work together to raise the profile of librarians and their areas of expertise. If institutions put a premium on preparing students to operate effectively in virtual public space as stewards of their discipline, faculty focused on their own research and careers will be more than willing to offload some of this burden to librarians. But issues in scholarly communication must be integrated into the curriculum with institutional force. Extracurricular (optional) interventions will be woefully inadequate. Lack of institutional commitment to change created the crisis in doctoral education. Only a strong, sustained commitment to digital literacy and the openness it entails can end it.

\section{References}

Ash, Joan. 1969. The Exchange of Academic Dissertations. College \& Research Libraries 30 (3): 237241. Accessed October 6, 2013. http://crl.acrl.org/content/30/3/237.full.pdf+html

Bishop, Patricia, Ruth Marshall and Debra Winter. 2007. A Robust Electronic Thesis and Dissertation Program at UCF. Research Bulletin, EDUCAUSE Center for Applied Research 2007 (3). Accessed October 5, 2013. http://net.educause.edu/ir/library/pdf/erb0703.pdf

Boyle, James. March 12, 2009. Cultural Agoraphobia and the Future of the Library. First Arcadia Lecture. Accessed October 5, 2013. http://linux02.lib.cam.ac.uk/arcadiaproject/podcasts/jame_boyle.mp3

Brown, Josh. 2010. Literature Review of Research into Attitudes towards Electronic Theses and Dissertations (ETDs). Accessed October 5, 2013. http://eprints.ucl.ac.uk/20424/1/20424.pdf

Carlson, David. 2013. Myths and Value in the Deposit of ETDs: A Final Teachable Moment. Accessed October 6, 2013. http://repository.tamu.edu//handle/1969.1/147902

Cassuto, Leonard. October 28, 2012. The Dissertation Defense: We're Doing Something Right. The Chronicle of Higher Education. Accessed October 6, 2013. http://chronicle.com/article/TheDissertation-Defense-/135386/

Clement, Gail P. and Fred Rascoe. 2013. ETD Management and Publishing in the ProQuest System and the University Repository: A Comparative Analysis. Journal of Librarianship and Scholarly Communication 1(4):eP1074. Accessed October 5, 2013. http://jlsc-pub.org/jlsc/vol1/iss4/1/

Copeland, Susan. 2008. Electronic Theses and Dissertations: Promoting 'Hidden' Research. Policy Futures in Education 6 (1): 87-96. Accessed October 5, 2013. https://openair.rgu.ac.uk/bitstream/10059/629/1/Copeland Policy Futures.pdf

Council of Graduate Schools (CSG). 2009. PhD Completion and Attrition: Findings from Exit Surveys of PhD Completers. Accessed October 5, 2013. http://www.phdcompletion.org/information/Executive_Summary_Exit_Surveys_Book_III.pdf 
Council of Graduate Schools (CSG). 2010. PhD Completion Project: Policies and Practices to Promote Student Success. Accessed October 5, 2013.

http://www.phdcompletion.org/information/Executive Summary Student Success Book IV.pdf

Dempsey, Lorcan. 2012. Managing Our Online Profersonal Lives. Accessed October 5, 2013. http://www.slideshare.net/lisld/managing-our-online-profersonal-lives

Digital Library and Archives: etds@vt. 2013. Accessed October 5, 2013. http://scholar.lib.vt.edu/theses/browse/by_author/

Disputations in the Collège de Sorbonne, 1344 A.D., Chartularium universitatis Parisiensis, II, I, 55456, translated by Lynn Thorndyke, University Records and Life in the Middle Ages (New York: W.W. Norton \& Company Inc.), 1975: 198-201.

Edminster, Jude and Joe Moxley. 2002. Graduate Education and the Evolving Genre of Electronic Theses and Dissertations. Computers and Composition 19 (1): 89-104. Accessed October 5, 2013. http://scholarcommons.usf.edu/cgi/viewcontent.cgi?article=1137\&context=eng_facpub

Ellis, Lindsay. September 30, 2013. Scholarly Groups Chip Away at the Taboo of Nonacademic Careers, Chronicle of Higher Education. Accessed November 2, 2013. http://chronicle.com/article/Scholarly-Groups-Take-On-a/141955/

Fineman, Yale. 2003. Electronic Theses and Dissertations. Portal: Libraries and the Academy 3 (2): 219-227.

FUSE (Free US ETDs). 2013a. Infographics Showing ProQuest ETD Coverage is Incomplete. Accessed October 6, 2013. http://sites.tdl.org/fuse/?p=757

FUSE. 2013b. The Curious Case of MIT (and why only they get to submit abstracts to ProQuest). Accessed October 6, 2013. https://sites.tdl.org/fuse/?p=402

FUSE. 2012-2013. Graduate Students Re-FUSE! Accessed October 6, 2013. https://sites.tdl.org/fuse/?page id=128

Fyffe, Richard and William C. Welburn. 2008. ETDs, Scholarly Communication, and Campus Collaboration: Opportunities for Libraries. College \& Research Library News 69 (3): 152-155. Accessed October 5, 2013. http://crln.acrl.org/content/69/3/152.full.pdf

Galarza, Alex. November 18, 2011. Don't Keep Your Head Down: Digital Dissertations and Graduate Training. gradhacker. Accessed October 5, 2013. http://www.gradhacker.org/2011/11/18/don'tkeep-your-head-down-digital-dissertations-and-graduate-training/

Getting a Degree, Antonino (1389-1459), Summa theologiae, III, 5, 2, 2, translated by Lynn Thorndyke, University Records and Life in the Middle Ages (New York: W.W. Norton \& Company Inc.), 1975: 309.

Golde, Chris M. 2006. Preparing Stewards of the Discipline. In Envisioning the Future of Doctoral Education: Preparing Stewards of the Discipline - Carnegie Essays on the Doctorate, edited by Chris M. Golde and George E. Walker. San Francisco, CA: Jossey-Bass: 3-20. Accessed October 5, 2013. http://media.wiley.com/product_data/excerpt/50/07879823/0787982350.pdf

Hadro, Josh. 2010. ProQuest Drops Dissertation E-Submission Fees. Library Journal. Accessed October 6, 2013. http://lj.libraryjournal.com/2010/09/academic-libraries/proquest-drops-dissertation-esubmission-fees/

Hames, Irene. 2012. Report on the International Workshop on Contributorship and Scholarly Attribution, May 16, 2012. Harvard University and the Wellcome Trust. Accessed October 5, 2013. http://projects.iq.harvard.edu/attribution_workshop/files/iwcsa_report_final_18sept12.pdf

Herther, Nancy K. 2010. Dissertations and Research in an Era of Change. Searcher 18 (2): 22-35.

Jaschik, Scott. September. 1, 2009. Money, Mentors, and Love. Inside Higher Ed. Accessed October 5, 2013. http://www.insidehighered.com/news/2009/09/01/grad.

Joint Information Systems Committee (JISC). April 2011. Developing Digital Literacies: Briefing Paper in Support of JISC Grant Funding. Accessed November 8, 2013. http://www.jisc.ac.uk/media/documents/funding/2011/04/Briefingpaper.pdf

Joint Information Systems Committee (JISC) and the British Library. June 2012. Researchers of Tomorrow: The Research Behavior of Generation Y Doctoral Students. Accessed October 5, 2013. http://www.jisc.ac.uk/media/documents/publications/reports/2012/Researchers-of-Tomorrow.pdf

"Literacy." Oxford English Dictionary, Oxford University Press, 2013. Accessed November 8, 2013. http://www.oed.com/view/Entry/109054?redirectedFrom=literacy

MacColl, John and Michael Jubb. 2011. Supporting Research: Environments, Administration and Libraries. Dublin, OH: OCLC Research. Accessed October 5, 2013. http://www.oclc.org/resources/research/publications/library/2011/2011-10.pdf 
McCutcheon, Angela M. 2010. Impact of Publishers' Policy on Electronic Thesis and Dissertation (ETD) Distribution Options within the United States. Accessed October 5, 2013. https://etd.ohiolink.edu/ap:10:0::NO:10:P10 ACCESSION NUM:ohiou1273584209

McMillan, Gail. 2005. Full Disclosure: How Authors and Readers Really Feel about ETDs. Presented at ETD2005 Conference, 8th International Symposium on Electronic Theses and Dissertations, University of New South Wales, Sydney, Australia, September 28-30, 2005. Accessed October 5 , 2013. http://docs.ndltd.org:8081/dspace/bitstream/2340/222/1/105McMillan.pdf

McMillan, Gail, Marisa L. Ramirez, Joan Dalton, Max Read and Nancy H. Seamans. 2011. An Investigation of ETDs as Prior Publications: Findings from the 2011 NDLTD Publishers' Survey. In Proceedings of the 14th International Symposium on Electronic Theses and Dissertations, Cape Town, South Africa, September 13-17, 2011. Accessed October 5, 2013. http://vtechworks.lib.vt.edu/bitstream/handle/10919/11338/PriorPubs4ETDs2011Paper.pdf?sequen $\mathrm{ce}=3$

Minocha, Shailey and Marian Petre. 2012. Handbook of Social Media for Researchers and Supervisors. UK: Centre for Research in Computing, The Open University. Accessed October 5, 2013. http://www.vitae.ac.uk/CMS/files/upload/Vitae_Innovate_Open_University_Social_Media_Handboo k 2012.pdf

Morris, Sean Michael. November 10, 2013. Queequeg's Coffin: a Sermon for the Digital Human. Hybrid Pedagogy. Accessed November 15, 2013.

http://www.hybridpedagogy.com/Journal/files/queequegs-coffin-a-sermon-for-the-digitalhuman.html

Myers, Katy and Alex Galarza. December 6, 2011. Best of GradHacker: Professional and Productivity. Inside Higher Education. Accessed October 5, 2013. http://www.insidehighered.com/blogs/gradhacker/best-gradhacker-professional-and-productivity

O'Donnell, James J. 1998. Avatars of the Word: From Papyrus to Cyberspace. Cambridge, MA: Harvard University Press.

Ong, Walter J. 1977. Interfaces of the Word: Studies in the Evolution of Consciousness and Culture. Ithaka, NY: Cornell University Press.

Ong, Walter J. 1982. Reading, Technology, and Human Consciousness. In Literacy as a Human Problem. Ed. By James C. Raymond. University of Alabama: University of Alabama Press: 170-201.

Patton, Stacey. May 6, 2012. The Ph.D. Now Comes with Food Stamps. Chronicle of Higher Education. Accessed November 2, 2013. http://chronicle.com/article/From-Graduate-School-to/131795/

Priem, Jason, Dario Taraborelli, Paul Groth and Cameron Neylon. 2011. Altmetrics: A Manifesto. Accessed October 5, 2013. http://altmetrics.org/manifesto/

ProQuest. History and Milestones. Accessed November 2, 2013. http://www.proquest.com/enUS/aboutus/history.shtml

Reich, Justin and Dennis Tenen. 2012. Book Proposal: Opening the Dissertation. Accessed October 6, 2013. http://www.edtechresearcher.com/project/opening-the-dissertation/

Sabga, Patricia. October 15, 2013. Adjunct Professors in Dire Straits with Low Pay, Lack of Full-Time Jobs. Real Money Matters, Aljazeera America. Accessed November 15, 2013. http://america.aljazeera.com/watch/shows/real-money-with-alivelshi/Real-MoneyBlog/2013/10/15/poor-working-conditionsforadjunctprofessorsleavestudentsshortcha.html

Salmi, Jamal Al. 2008. Factors Influencing the Adoption and Development of Electronic Theses and Dissertations (ETDs) Programs, with particular Reference to the Arab Gulf States. Information Development 24(3): 226-236. Accessed October 5, 2013.

http://idv.sagepub.com/content/24/3/226.abstract

Salutati on Disputations, Leonardi Aretini ad Petrum Paulum Istrum Dialogus, in Theodor Klette, Beiträge zur Geschichte und Litteratur der italienischen Gelehrtenrenaissance, II (1889), 4-47, 52-53, translated by Lynn Thorndyke, University Records and Life in the Middle Ages (New York: W.W. Norton \& Company Inc.), 1975: 266-269.

Seamans, Nancy H. 2003. Electronic Theses and Dissertation as Prior Publications: What the Editors Say. Library Hi Tech 21 (1): 55-61. Accessed October 5, 2013. http://digitalarchive.gsu.edu/univ_lib_facpub/42/

Smith, Kevin. July 7, 2012. Dissertations for Sale, or, Scaring the Children, Part 2. Scholarly Communications@Duke. Accessed October 5, 2013.

http://blogs.library.duke.edu/scholcomm/2012/07/07/dissertations-for-sale-or-scaring-the-childrenpart-2/ 
Sowell, Robert. March 31, 2008. PhD Completion and Attrition: Analysis of Baseline Data. Council of Graduate Schools. Accessed October 5, 2013. http://www.phdcompletion.org/resources/CGSNSF2008 Sowell.pdf

Suber, Peter. July 2, 2006. Open Access to Electronic Theses and Dissertations (ETDs). SPARC Open Access Newsletter 99. Accessed October 5, 2013. http://www.earlham.edu/ peters/fos/newsletter/07-02-06.htm - etds

Swain, Dillip K. August 2010. Global Adoption of Electronic Theses and Dissertations. Library Philosophy and Practice 2010. Accessed October 5, 2013. http://unllib.unl.edu/LPP/dillip-swain.htm

Tarrant, Anna. January 19, 2012a. Part 1: Should You Make Your Thesis More Widely Available Online? PhD2Published. Accessed October 5, 2013. http://www.phd2published.com/2012/01/19/should-you-make-your-thesis-more-widely-availableonline-part-1/

Tarrant, Anna. February 9, 2012b. Part 2: Should You Make Your Thesis More Widely Available Online? Fear of Idea Theft. PhD2Published. Accessed October 5, 2013. http://www.phd2published.com/2012/02/09/part-2-should-you-make-your-thesis-more-widelyavailable-online-fear-of-idea-theft/

Torres, Manuel R. June 24, 2012. Dissertation for Sale: A Cautionary Tale. The Chronicle of Higher Education. Accessed October 5, 2013. http://chronicle.com/article/Dissertation-for-Sale-A/132401/

Woodmansee, Martha and Peter Jaszi. 1995. The Law of Texts: Copyright in the Academy. College English 57 (7): 769-787.

Yiotis, Kristin. 2008. Electronic Theses and Dissertation (ETD) Repositories: What are they? Where do they come from? How do they work? OCLC Systems \& Services 24 (2): 101-115. 